\title{
The EU's hegemonic interventions in the South Caucasus: constructing 'civil' society, depoliticising human rights?
}

Laura Luciani, Centre for EU Studies, Department of Political Sciences, Ghent University (Universiteitstraat 8, B-9000 Ghent, Belgium); laura.luciani@ugent.be

NOTE: This is the Accepted Manuscript of an article published by SAGE in Cooperation and Conflict on 03 September 2020 (online first), available at: https://journals.sagepub.com/doi/10.1177/0010836720954478

Please cite as: Luciani, L. (2021) The EU's hegemonic interventions in the South Caucasus: Constructing 'civil' society, depoliticising human rights?, Cooperation and Conflict, 56(1):101-120. DOI: $10.1177 / 0010836720954478$.

\begin{abstract}
This article draws upon poststructuralist and postcolonial theories to examine the European Union's (EU's) policies of human rights promotion in the South Caucasus - notably, the EU's engagement with local human rights activists and organisations in Armenia, Azerbaijan and Georgia. Contrary to most literature, which has been concerned with policy (in)effectiveness, this article is interested in problematising the discursive foundations of this EU-civil society 'partnership' in the realm of human rights promotion, as well as in retrieving the agency of actors who are 'at the receiving end' of EU policies. It is argued that the discursive construction of 'civil' society as a 'good-Other' of the EU-Self serves as a means to depoliticise the EU's interventions, aiming at the approximation of 'transitioning' countries to the EU's human rights standards. Although the hegemonic relation requires subaltern actors to perform the 'civil' society identity, processes of hybridisation and subversion arise as external interventions interact with local realities and meanings. Building on indepth interviews and ethnographic observations, the article shows how the hegemonic identity of 'civil' society is negotiated by South Caucasus 'not-quite-civil' actors striving for local legitimacy, financial survival or ownership of their human rights work.
\end{abstract}

Keywords: European Union; civil society; human rights promotion; South Caucasus; hegemony 


\section{Introduction}

Civil society is a crucial piece in the European Union's (EU) external action framework in the domain of human rights promotion (hereafter, HRP). Since the collapse of the Soviet Union, and even more so since the launch of the Eastern Partnership (EaP) in 2009, the EU has been engaging with civil society actors in the South Caucasus (Armenia, Azerbaijan and Georgia), considering them as important partners in the bottom-up promotion of human rights, democracy and the rule of law. For local human rights activists and civil society organisations (CSOs) this has meant not only increased funding (e.g. through a Civil Society Facility dedicated to the EU's 'neighbourhood'), but also the opening up of opportunities to participate in policy developments, notably through the Eastern Partnership Civil Society Forum (EaP CSF) ${ }^{1}$ : more engagement with civil society appeared as one cross-cutting deliverable among the "20 deliverables for 2020 " set by the EU and EaP countries. Whereas most European studies literature has been concerned with policy (in)effectiveness and norms diffusion, related to the extent in which the EU managed to socialise or 'empower' civil societies in third countries, including the South Caucasus (Aliyev, 2016; Rommens, 2014; Smith, 2011), the discursive foundations underpinning this EU-civil society 'partnership' have been by and large taken for granted. To counter these dominant perspectives, this article unpacks the discursive foundations of these policies through poststructuralist and postcolonial theories by asking: how is "civil society" constructed and subverted within the EU's HRP in the South Caucasus?

External support to civil society has been problematized by a number of scholars, which departed from the focus on norms diffusion to expose the dysfunctionalities generated by the 'marketization' of civil society (Choudry and Kapoor, 2013; Cooley and Ron, 2002; Hahn-Fuhr and Worschech, 2014; Hulme and Edwards, 2013; Marchetti, 2017). While these contributions expose how foreign funding, including the EU's, affects the motivations, claims and accountability of local nongovernmental organisations (NGOs), they are overwhelmingly based on rationalist premises. In the camp of poststructuralist approaches, Foucauldian governmentality theory has dominated the field of European studies since Kurki's (2011a) seminal work: this illuminated the neoliberal and depoliticizing rationalities informing EU support to civil society, notably through the European Instrument for Democracy and Human Rights (EIDHR). However, as Muehlenhoff (2018) rightly notes, governmentality studies mostly analyse EU documents, overlooking how civil society support

\footnotetext{
${ }^{1}$ This was set up in 2009 as a EU-funded platform aimed at facilitating and strengthening the "active and expert" engagement of civil society in promoting European integration in the region.
} 
works in practice within a specific context and how its rationalities are negotiated by local actors. In light of these elements, this article advances the problematization of EU engagement with civil society in a two-fold way: first, by employing Laclau and Mouffe's (1985) theory of hegemony and Bhabha's concept of hybridity (1984), it contributes to a discursive-theoretical understanding of these policies, also beyond the governmentality framework. Notably, it conceptualises them as hegemonic interventions shaping the identity of civil society and its role in HRP. Second, by illustrating how this identity gets hybridized and subverted in the South Caucasus context, this contribution suggests a mutually constitutive relation between EU paradigms and local agencies.

In line with invitations to 'decentre' the study and practice of EU foreign policy, this article examines the contingent, EUrocentric ${ }^{2}$ assumptions underpinning EU normative paradigms and the power/knowledge relations they sustain (Fisher Onar and Nicolaidis, 2013; Keukeleire and Lecocq, 2018). As Diez (2013: 204) suggested, the concept of hegemony provides a fruitful entry point for such exercise: it allows to "denaturalise the norms that are brought into association with the EU" by spotlighting the discursive struggles about and the politics sustaining them. Authors have illustrated how the EU positions itself as a benevolent hegemonic power in its Eastern 'neighbourhood', and how the EaP enacts the EU's desire to "promote its own established order inside-out" by shaping 'transitioning' post-Soviet countries through 'universal' norms and structures similar to its own (Korosteleva, 2017: 322; also Haukkala, 2008; Horký-Hlucháň and Kratochvíl, 2014). ${ }^{3}$ Against this backdrop, this contribution explores how the EU's human rights interventions in the South Caucasus materialise in financial and political support to a 'civil' society, whose boundaries are shaped and whose practices disciplined according to the hegemon's rules of the game. Moreover, by casting light on processes of re-articulation and subversion, it retrieves the "critical and discursive agency" of actors at the receiving end of EU policies (Richmond, 2011: 420).

As it examines the EU's engagement with civil society in the framework of its HRP policies (HRP via civil society), the article focuses on one sector of the local civil society, i.e. actors dealing with human rights. The analysis is based on data generated through what Feldman (2011) calls a "nonlocal ethnography": a flexible methodology that is not fixed to a few places, but equally allows for

\footnotetext{
${ }^{2}$ The term 'EUrocentric' indicates the EU's hegemonic position in defining the notion of Europe (cf. Kulpa, 2014).

${ }^{3}$ Arguably, after revising the European Neighbourhood Policy in 2015, the EU restated its commitment to differentiation in its bilateral relations with its 'neighbours', recognising that not all partners aspire to EU rules and standards; however, these were not called into question and reaffirmed as 'the normal' (Korosteleva, 2017).
} 
critiquing "the hegemony of 'common knowledge' and trac[ing] the role of contingency in human affairs" (ibid.: 47). The methods used were interviews, participant observation and the analysis of EU official documents, statements and policy papers. 28 in-depth semi-structured interviews were conducted between March-September 2019 with EU officials and civil society representatives (See List of Interviews). An initial list of interviewees was compiled by building on the EaP CSF membership database, as well as personal contacts with Brussels-based donor organisations and South Caucasian CSOs. Further respondents were snowballed based on interviewees' referrals, which was useful to approach more grassroots/informal actors. ${ }^{4}$ Several dozen pages of field notes were generated through participant observation during public policy events in Brussels (involving EU officials and South Caucasian human rights actors) and visits to CSOs' offices. Written sources were selected in light of their foundational policy character, to obtain further information about EU-civil society cooperation in a specific country, and/or to triangulate information generated through interviews. These physical and non-physical sites of data generation helped illuminating the discourses, articulated in multiple policy settings from the EU- to the local level, which enable the construction of the EU's HRP via civil society in the South Caucasus (Feldman, 2011). Adopting an interpretive approach, the goal was to "map" different settings "for exposure to a variety of possible meanings / interpretations within them concerning the matter of interest" (Yanow, 2014: 148).

First, the article problematizes the concept of civil society as it is framed in EU external policies. Then, it provides a framework to analyse the EU's HRP via civil society as hegemony. In the empirical part, it examines the discursive construction of civil society in the South Caucasus by focusing on two processes: how 'civil' society is articulated as a 'good-Other' of the 'EU-Self', and how this hegemonic identity is negotiated by local actors. The conclusions reflect on the consequences of these discursive processes for the politics of EU HRP via civil society.

\section{Civil society as a means to an end in EU external relations ${ }^{5}$}

The involvement of civil society first appeared in the EU's internal governance agenda in the early 2000s, as a palliative for the EU's own 'democratic deficit' (Kutay, 2017). Over the years, it became central within EU external action, following an already established "global political project of

\footnotetext{
${ }^{4}$ This study aimed for exposure to a diverse range of actors - i.e. organisations with a formal structure and with a looser one, individual activists, that are and are not funded by the EU.

${ }^{5}$ This section partly draws upon Vandeputte and Luciani (2018).
} 
building democracy and peace around the world" (Beraia et al., 2019). Despite the EU's attempts at defining 'civil society', this remains a contested concept characterised by "acute definitional fuzziness" (Hahn-Fuhr and Worschech, 2014: 15). In its neo-Toquevillian understanding, which dominates (Western) public discussions, it is characterised by being distinct from the government and the market. In EU external action, support to civil society comes with a series of normative assumptions emphasizing its value-added as a 'force for good': "an empowered civil society, in all its diversity, represents a crucial and integral component of any democracy and constitutes an asset in itself" (Council of the European Union, 2012). Following a functionalist perspective, which focuses on civil society actorness and contribution to democracy/democratization, scholars discerned two major theories: the liberal view considers civil society as a counterpart to the state, fulfilling a 'watchdog' role in checking on the government, defending citizens' rights and disseminating information that empowers citizens in the pursuit of their interests and values. The republican view sees civil society as complementary to the state, providing basic socialisation functions among which democratic participation, the generation of social capital and the support for structural economic reforms (Hahn-Fuhr and Worschech, 2014).

Both dimensions are mobilised in the EU's approach: financial support to civil society and the creation of an 'enabling environment' for it to operate are seen as conducive to the consolidation of third countries' democratic and human rights standards, as well as to economic liberalisation. In some cases, direct support (e.g. through the EIDHR or the European Endowment for Democracy) can be provided by the EU without third country governments' consent, and civil society actors be directly involved in policy-making - especially if "partner countries show only limited commitment to [change]" (Council of the European Union, 2012; see also Council of the European Union, 2017). However, in fostering 'transition' and 'developing' countries' transformation towards liberal democracy and market economy, the EU requires civil society "to assume a role of service provider in society, thereby reducing the responsibilities of the state, yet not challenging the state's stability" (Axyonova and Bossuyt, 2016: 5). Though in its narrative the EU emphasises a political role for civil society, in the implementation of human rights and democracy assistance programmes CSOs are meant to fulfil an apolitical role, limited to the provision of socio-economic services (Boiten, 2015)

\footnotetext{
${ }^{6}$ The EU defines civil society as "all non-State, not-for-profit structures, non-partisan and non-violent, through which people organize to pursue shared objectives and ideals, whether political, cultural, social or economic" (European Commission, 2012).
} 
or of technical expertise related to legal harmonisation with EU standards, as in EaP countries (Böttger and Falkenhain, 2011; Buzogány, 2018).

Based on the 'local ownership' principle endorsed across EU external policies, civil society is considered well placed for promoting democratic transformations in a bottom-up, grassroots way. As 'universal' representatives of the wider society (Boiten, 2015), civil society actors are presented as the 'prime owners' of human rights and democracy in the world. This implies they are supposed to be "rooted in societies in order to provide legitimacy from below", yet paradoxically they need to be formally organised to deal with the EU's (often burdensome) funding procedures (Marchetti, 2017: 280). Due to these bureaucratic constraints, EU civil society support primarily targets NGOs: these became synonym with civil society, even though they represent only a narrow, neo-liberal form of what might be subsumed under this concept. NGOs are said to be characterised by a formal, institutionalised and professionalised structure, financial dependence on (Western) donors and an orientation towards their agendas rather than towards local claims or needs (Cooley and Ron, 2002; Hulme and Edwards, 2013). Especially in post-communist contexts, the applicability of such model has been widely criticised (Abramson, 1999; Beraia et al., 2019; Ishkanian, 2014; Matveeva, 2008), not only because of its questionable effectiveness in generating sustained social transformations (Aliyev, 2015; Hahn-Fuhr \& Worschech, 2014), but also as a project meant to impose Western hegemony and prevent the recognition of grassroots civil society (Babajanian et al., 2005). In the words of one interviewee:

"We are forced, after the Soviet period, to develop fast. Even CSOs were created from the top, from donors' influence. Without any ground development, any activism development [...] First there were civil [society] organisations, and only now sporadic actions of activism are happening in Georgia. We do not have any social movements strong enough to demand and influence" (Interview 13)

Though NGOs are said to pluralise the institutional arena, critical scholars argued that support to professionalised organisations can undermine democratic developments. They found that donors' focus on NGOs contributed to the depoliticization of social movements and their disciplining into intelligible institutions, "so that they would not demand radical change, directing their efforts on social reform instead, and being safe for the existing order / system" (Beraia et al., 2019; see also Choudry and Kapoor, 2013; Hulme and Edwards, 2013). Along these lines, contributions focusing on EU funding instruments characterise civil society support as neoliberal governmentality (Kurki, 
2011a; Muehlenhoff, 2018): it addresses a westernised, professionalised and ideologically liberal civil society that, through specific technologies and rationalities, is expected to work as service provider or mediator purporting non-ideological (lobby) positions, within a development paradigm that "continues to be market-led" (Hurt, 2006, in Axyonova and Bossuyt, 2016: 5). Grassroots movements and politically significant actors are left aside from support programmes 7, together with community-based forms of civil society (e.g. based on shared traits of religion, ethnicity or class), and more conservative actors (Boiten, 2015).

To sum up, in its external relations, the EU promotes civil society not only as an asset in itself, but as a 'means to an end' for the attainment of a liberal democratic and economic transition, as well as for the spread of EU values and partner countries' approximation to these. I will now clarify the theoretical foundations allowing to unpack these policies as hegemony.

\section{A framework for analysis}

This article understands hegemony as "a form of rule based on the acceptance by a community of a particular discursive-political order as consistent with the universal ideal” (Morozov, 2018: 39). The "community" comprises the South Caucasian human rights activists and CSOs: they recognise themselves in EUropean values and norms, "perceiv[ing] their way of life as part of a certain legitimate universal order" (ibid: 34). However, as 'Eastern neighbours', they are constructed as an "ambiguous and transitional Other", finding themselves in a subaltern position vis-à-vis the EU (Horký-Hlucháň and Kratochvíl, 2014: 255). According to this interpretation, accepted by poststructuralists, the hegemon's power lies not in coercion, but in discourse and ideology: it is a form of rule by consent.

Discourse represents a structure where meaning is constantly struggled over (Laclau and Mouffe, 1985). Political interventions can (only partially) fix meaning through the practice of articulation, whereby "privileged signifiers - nodal points - are attached to a chain of signification" (Morozova, 2018: 365). Such is the relation between "civil society" and "NGOs", and their link to concepts as "local ownership", "human rights", “democracy" or "development". Articulations establish "a relation among elements such that their identity is modified as a result of the articulatory practice"

\footnotetext{
${ }^{7}$ The European Endowment for Democracy is an exception. Created in 2013 by the EU and EU member states, it is a demand-driven instrument meant to support not only NGOs but also political parties, individuals and grassroots initiatives in the EU's 'neighbourhood'. Though its establishment might signal a shift in EU civil society support, its contribution in terms of financial allocation remains marginal.
} 
(Laclau and Mouffe, 1985: 105): the identity of "civil society" is constructed simultaneously along two dimensions - a process of linking and a process of differentiation/othering - through a series of juxtaposed signifiers, which define how the subject is and how it is not (Hansen, 2006). These representations provide subject positions for the subalterns, which they have to follow in order to be regarded as (real) "civil society” actors (Jørgensen and Phillips, 2002: 43). The discursive element "civil society" constitutes a nodal point in the EU's HRP discourse; simultaneously, it is open to different ascriptions of meaning - representing a "floating signifier" in the struggle between the EU official discourse and different, context-specific discourses mobilised by subaltern actors, that will be unpacked below (Laclau and Mouffe, 1985).

Conceptualizing the EU's HRP via civil society as hegemony allows us to understand how the EU attempts at stabilizing these policies' contingent meaning as the norm(al). In the EaP, therefore in its relations with the South Caucasus countries, the EU managed to present its normative agenda as a set of "common values" (in reality, monopolised by the EU) - with a focus on the partner countries' legal approximation to these norms (Haukkala, 2008; Horký-Hlucháň and Kratochvíl, 2014). Consent for human rights reforms was shaped through soft conditionality, incentives such as freetrade agreements or visa liberalisation regimes, as well as financial, technical and political support to civil society - presented as the 'natural' vehicle for the bottom-up, locally owned transformation of 'transitioning' countries. Based on technical and bureaucratic solutions aimed at removing the risk of contestation, EU policy practices are depoliticizing (Korosteleva, 2017): they represent interventions performed in the realm of "politics", "within a settled agenda or framework that is taken for granted" (Edkins, 2007: 93). Notably, the EU's rhetorical claim is that it promotes the 'universality and indivisibility of human rights and fundamental freedoms' (art. 21 TEU), implying a consensus over these rights: this is what Kurki (2011b: 1582) describes as a "harmonious" discourse, "where all rights are seen to push in the same direction of liberal democracy and development". ${ }^{8}$ This articulation conceals the existence of a variety of struggles, which become manifest within the local civil societies: for example, among those who support a more liberal understanding of rights as individual freedoms and those who support a socialist conception with heavier commitment to positive action. Besides, conservatives can revolt against 'progressive' norms (e.g. LGBT rights)

\footnotetext{
${ }^{8}$ Despite increasing efforts from within the bloc to decline human rights norms in illiberal ways, the EU restated its commitment to the universality and indivisibility of these norms in its external action, notably in its 2019 Council Conclusions on Democracy and the most recent Action Plan on Human Rights and Democracy 2020-2024.
} 
promoted by the hegemon, as these "undermine [their] privileged position in local structures of inequality" (Morozov, 2015: 19). Struggles also materialise around how human rights should be conquered - rather than advocated or lobbied for. According to Evans (2005), the hegemonic human rights discourse (to which the EU subscribes) rests on the idea of an institutionalised legal regime that sustains rather than challenges structural inequalities, espousing the idea of free market economy as beneficial for democracy, human rights and development. This "raises questions about the role and status of many NGOs that seek to promote human rights through formal means" (Evans, 2005: 16) - privileging polite reformism over radical contentious action (Choudry and Kapoor, 2013).

Within the hegemonic relation, subaltern actors in the South Caucasus are required to perform the norms articulated by the EU. However, they constantly navigate "between two conflicting impulses, to catch up and to preserve a unique identity" (Morozov, 2015: 109). This tension between the universal and the particular links with the concept of hybridity coined by postcolonial scholar Homi Bhabha (1994), who stressed the complex and heterogeneous identities of the colonised. While they strive to comply with and mimic the EU-niversal ideal, the subalterns can never fully assimilate: this results in a hybrid identity which Bhabha defines as "almost the same, but not quite" (1994: 86). The non-fixed nature of discourse and the negotiation of heterogeneous identities allow the subalterns to inscribe new meaning into the signifier "civil society", through independent thinking or action: this is how critical agency manifests itself. As Richmond (2011) suggested, it does not involve open contestation, but rather hybrid and subversive forms of resistance: having seemingly adopted the hegemonic knowledge, subalterns are "not only complicit in its reproduction but also simultaneously misappropriating and perverting its meaning, thereby circumventing, challenging and refusing colonial authority" (Morozov, 2015: 22-23). Subaltern actors are thus involved in a struggle over meaning, a re-articulation of the discursive space, which makes alternative interpretation of the hegemon's paradigms possible and relevant (Diez, 2013). These processes disclose what Edkins calls the Political "with a capital 'P'", representing an opportunity for "openness" and for the (partial) unsettlement of the established order (1999, in Korosteleva, 2017: 323).

In short, this framework suggests a mutually constitutive relationship: while the hegemon aims at discursive closure by articulating the paradigms it promotes as common sense - depoliticizing them, in reality this intervention entails continuous hybridization and subversion by the subaltern actors, which reveals its inherently contingent (thus, political) nature. The analysis presented below 
focuses on the discourses mobilized by EU and human rights actors: it examined how the concept of "civil society" was articulated therein, which identities were linked together and which were excluded, and how these articulations relate to broader discourses about civil society's role in HRP.

\section{The articulations of 'civil society' in the South Caucasus}

The EU requires local civil societies to be involved in the political transformations it seeks to achieve in the 'neighbourhood' - so as to foster 'ownership'. In the South Caucasus countries, the institutional and socio-political context shaping EU-civil society interactions is very diverse: while Georgian civil society is said to be "very active and well organised" (Interview 8) in its interactions with the EU - mainly thanks to the government's pro-Euro-Atlantic stance, in Azerbaijan the EU's engagement with civil society is heavily hampered by legal restrictions on foreign funding, crackdown on human rights activists, absence of policy dialogue, and the government's lack of interest in pursuing closer ties with the EU. In Armenia, the so-called 'Velvet Revolution' of spring 2018 led to a major reconfiguration of the previously 'shrinking' space for civil society, also putting the spotlight back on its transformative potential. ${ }^{9}$ Despite these differences, the EU consistently applies a "one-size-fits-all" approach in its relations with civil society (Aliyev, 2016: 44). Asked whether the EU should re-think its approach to HRP via civil society in Azerbaijan, given the country-specific challenges, one EU official responded that "there is no need to be creative", and suggested the EU sticks to its "rules and principles" (Interview 15).

Human rights CSOs are systematically involved in a consultation process before the EU's political dialogue meetings with partner governments, with an important role played by the EU Delegations. In Georgia, they have become stakeholders in the process of reforms sought by the EU through mechanisms such as the EU-Georgia Civil Society Platform for the implementation of the Association Agreement (AA) signed in 2014, and thanks to the adoption of a EU-backed National Human Rights Strategy and related Action Plan (Interview 8). Since Armenia signed a Comprehensive and Enhanced Partnership Agreement (CEPA) with the EU in December 2017 10, an EU-Armenia Civil Society Platform is being set up to allow CSOs from both sides to follow up

\footnotetext{
${ }^{9}$ The wave of peaceful demonstrations that took place between April and May 2018 led to the end of a twentyyear rule of the Republican Party of Armenia.

${ }^{10}$ In 2013, Armenia was unable to sign its earlier negotiated Association Agreement (AA) and Deep and Comprehensive Free Trade Area (DCFTA) with the EU, due to Russian pressure to join the Eurasian Economic Union. In 2017, the CEPA, a sort of Association Agreement-light was signed with the EU, from which freetrade arrangements are excluded. Before that, a formal EU-related mechanism for civil society monitoring and dialogue existed in the GSP+ scheme from which Armenia is benefiting since 2014.
} 
on the agreement's implementation - albeit not without certain problems (see below). Azerbaijani civil society is currently not involved in any EU-related structured mechanism, besides the EaP CSF. However, respondents expressed hope that the ongoing negotiations for a new EU-Azerbaijan agreement lead to some improvement (Interview 19; 21; 22) - with EU representatives assuring that opening up the civic space is "a red line" in talks with the government (personal observation, Baku, 12.09.19).

\subsection{Constructing a 'good-Other' of the 'EU-Self'}

Civil society is supposed to fulfil its role by advocating for EU-sponsored human rights reforms, acting as a watchdog in monitoring their implementation, while establishing a constructive relation with the state - to which they provide policy advise and technical expertise (Interview 1; 4; 10; 19; personal observation, Brussels, 26.02.19). To be more effective and have a stronger voice in conveying claims, CSOs are expected to work together within specific platforms to reach consensus and build coalitions ensuring greater representativeness (Interview 1, 4). This vision of civil society's role seems to reflect the EU's consensus-based, technical and incremental internal mode of working. It can be argued that the EU's construction of civil society corresponds to the articulation of a "goodOther" of the EU-Self (Figure 1). 


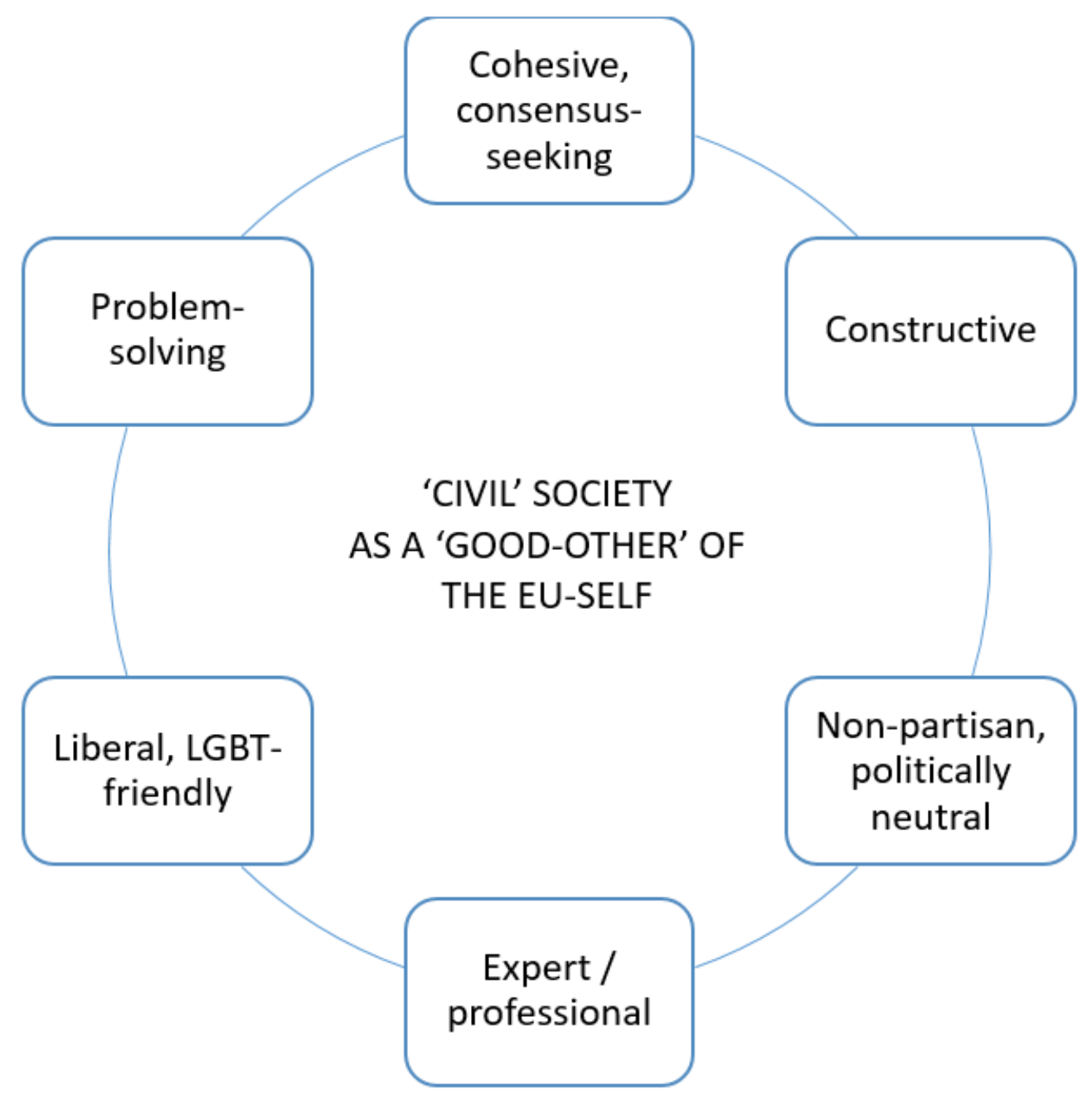

Figure 1. The articulations of 'civil society' - positive identity (author's elaboration).

The 'good-Other' identity describes a civil society which is political (being involved in policy developments and working on politically significant issues) but works in an apolitical manner, i.e. through non-ideological advocacy and by 'sitting at a table' with the government, notwithstanding internal and external political frictions. As already noted by Boiten (2015) in her examination of EU democracy assistance in Tunisia, the fact that human rights actors (even working in the same field) have different political views, diverging interests or opinions about the forms of action to undertake towards a specific goal, seems to leave EU representatives puzzled and is described as 'problematic'. In the case of Armenia, one EU official described the situation as such:

"[The CSOs] need to further develop a sense for cooperation and consensus-building, to create respective working groups, to be able to follow the implementation of the [CEPA] and provide policy advice. Now at the beginning of the process we see challenges to reach 
agreement on some aspects, we encourage them to articulate their needs because the external consultants are ready to support this process." (Interview 4)

Similar issues are witnessed in the Georgian National Platform of the EaP CSF, which several leading human rights CSOs have left, "reflecting divergent views" and "disagreements with the government whom they try to hold accountable" (European External Action Service, 2018: 6; also interview 11). In Azerbaijan, where consultations with human rights activists and organisations are of an ad-hoc nature, an EU official suggested that local actors are "split" due to more lenient or critical attitudes vis-à-vis the government (see below), which forces the EU to "have to consult many people to make conclusions" before issuing official reports (Interview 15).

Civil society also needs to be professional: on the one hand, professionalism is the capacity to provide technical expertise to policy-makers, and to advocate vis-à-vis the government and the EU - for example by producing shadow reports or policy papers (Interview 1; 19; personal observation, Brussels, 21.02.19). On the other, there is a widespread knowledge, both in policy and academic circles, that civil society in Eastern Europe is 'weak', compared to its Western European counterparts (Aliyev, 2015). Instead of acknowledging that civil society may have more informal or less 'civil' local declinations, professionalism is supposed to be built up through EU trainings and grants aimed at capacity-building: civil society is taught how to do advocacy, foster change and constructively communicate with stakeholders (Interview 4). Despite the crucial role assigned to them by EU officials and the liberal-democratic 'partnership' rhetoric, local civil society actors are often referred to as "lacking capacities", needing to be supported by "EU experts" and to be "brought up to the European standards" - as interviewees confirmed (informal conversation, Armenian human rights activist, 8.11.18; informal conversation, Georgian women's rights NGO, 16.05.19; also interview 2; 20). Kulpa (2014: 431) describes this as "leveraged pedagogy": a "hegemonic didactical relation where [Central and Eastern Europe] figures as an object of the West/European 'pedagogy', and is framed as permanently 'post-communist', 'in transition' (i.e. not liberal, not yet, not enough)”. 


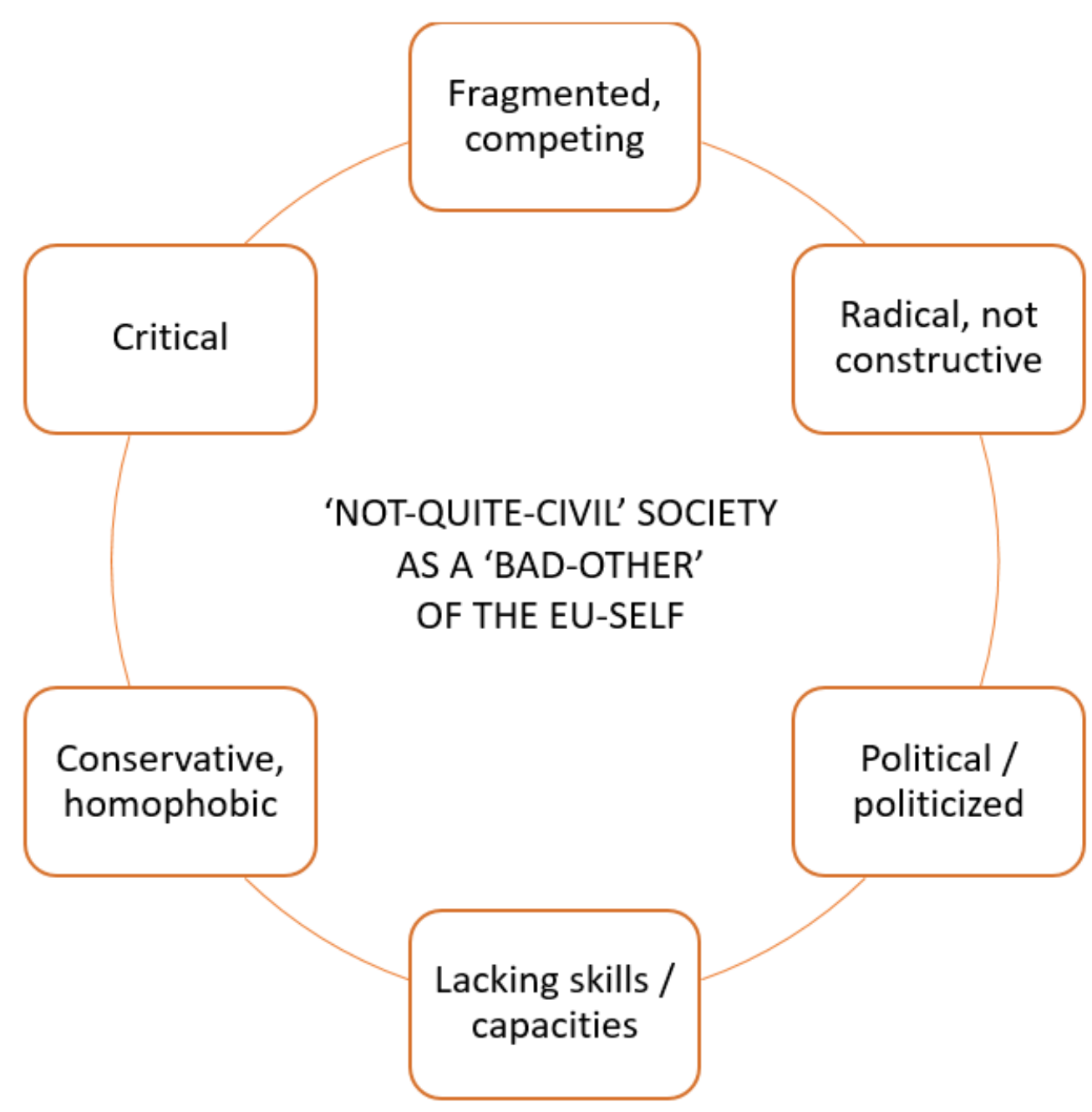

Figure 2. The articulations of 'civil society' - negative identity (author's elaboration).

For a hegemonic identity of 'civil' society to be normalized (Figure 1), it is posited as different from a 'not-quite-civil' society (Figure 2). Let us now focus on the exclusionary signifiers around which a negative identity is articulated. First, data generated through fieldwork show that forms of potentially disruptive contentious politics (demonstrations, protests, or riots), are not seen as legitimate forms of action that could be undertaken in the name of human rights, equality or social change. Through the use of political representations, i.e. by labelling some actors as "not constructive" or "radical", the hegemonic discourse sets the boundaries of what is 'civil' (Interview $2 ; 4 ; 5 ; 12)$. However, these boundaries are quite ambiguous: for example, while nowadays EU observers praise Armenia's Velvet Revolution as 'a victory of civil society', one year before that same civil society was being criticized by the donor community "for being an overly politized [sic] and unconstructive civil society that should instead be sitting around a discussion table with the government to assist in reforms" (Socioscope, 2019: 19). The juxtaposition between 'good' civil 
society internalising the neutral mediator's role, and 'bad' civil society showing critical agency reminds of Robert Cox's famous distinction between 'problem-solving' and 'critical' theories (see Richmond, 2011).

Second, "conservative" and "homophobic" are also political representations excluding actors from 'civil' society. The fact that some Armenian human rights NGO representatives (notably, the older generation which grew up in Soviet times) may not be supportive of the anti-discrimination legislation ${ }^{11}$ which covers all grounds of discrimination, including the locally contested 'sexual orientation and gender identity', "illustrates the lack of understanding of the universality of human rights" - according to a respondent (Interview 4). These articulations do not only reflect a normative view of civil society, but also the hegemonic expectation that post-Soviet societies quickly catch up with the liberal and tolerant values supposed to pertain to EUrope, such as LGBT-friendliness (Kulpa, 2014; also interview 8). Thus, "civil society rhetoric works as a symbolic opposition to elements deemed outside the civil order, in an attempt to foster the hegemony of civility" (Schneider and Schneider, 1998, in Abramson, 1999: 247).

Last but not least, these articulations conceal that "the concept of human rights supports competing conceptions that give a focus to deeply rooted political struggles" (Evans, 2005: 16). Human rights policies become depoliticized, technical activities, to be assessed against quantitative indicators, with civil society playing the role of politically neutral mediators. The "Eastern Partnership Index" is an example of this: first developed by the Open Society Foundation and now taken over by the $\mathrm{EaP} \mathrm{CSF}$, it "charts the progress made by the six EaP countries towards sustainable democratic development and European integration". ${ }^{12}$ Building on information gathered by EaP- and EU-based CSOs, the Index reaffirms the primacy of EU norms and classifies EaP countries among 'frontrunners' or 'laggards' when it comes to 'approximation' - a terminology interiorised by human rights actors themselves (Interview 10; 22).

\subsection{Negotiating the hegemonic discourse with local realities}

The discursive construction of "civil society" both depends on and is constitutive of policy practices performed by EU and local actors. As interviewees noted, these are established not upon a 'partnership', but upon a fundamentally unequal relationship (Interview 2; 3; 5; 7; 12; 20; informal conversation, Georgian scholar 20.05.19). This last section provides illustrations of how subaltern

\footnotetext{
${ }^{11}$ One of the benchmarks of the EU-Armenia Human Rights Budget Support Programme agreed in 2015.

${ }^{12} \mathrm{EaP}$ CSF website: https://eap-csf.eu/eastern-partnership-index/
} 
actors in Armenia, Georgia and Azerbaijan negotiate the "civil society" identity through processes of hybridity and subversion - resulting in "almost the same, but not quite" (Bhabha, 1994: 86). It will address three (interrelated) issues - and subaltern actors' strategies to navigate these: human right actors' dependence on EU funding; the politicization of the civic sector; the tension between external interventions and local legitimacy dynamics.

First, human rights CSOs' independence from EU/Western donors' financial support is almost nonexistent in the South Caucasus, particularly for CSOs located outside capital cities (Aliyev, 2015). This has two consequences: on the one hand, fragmentation among human rights actors - as opposed to the represented cohesive 'civil' society - is high due to a strong competition for funding, which stands at the very basis of Western/EU neoliberal system of civil society support (Interview 2; 3; 9; informal conversation, Georgian women's rights NGO, 16.05.19). ${ }^{13}$ Ironically, foreign aid to civil society "is often enabling of incivility" (Abramson, 1999: 246): respondents suggested that, while CSOs may form temporary, issue-oriented coalitions, or work on projects together, it is "the most natural thing" that they have different interests and "go their own way" (Interview 18). Eloquently, the director of a Georgian women's rights NGO said that the EU's practice of pushing CSOs to cooperate, for example through sub-granting schemes, reminds of "forced marriage" (informal conversation, 16.05.19). On the other hand, observations show that, despite expectations they would work in a 'professional' manner, human rights CSOs in the region often struggle to obtain the necessary resources to function on a basic level:

"We very much imagine NGOs with offices, permanent staff... there is nothing like this in reality" (Interview 15)

Second, civil society in the South Caucasus is more politicized than the hegemonic discourse would wish. As a general point, it is disputable to what extent the EU can work with "really independent" human rights actors (as opposed to government-organised non-governmental organisations, GONGOs) when those are "funded by international or foreign national organisations which are in turn funded by foreign governments" (Abramson, 1999: 242). Moreover, according to local power configurations, the boundaries between the political and the civic sphere can be extremely porous. For instance, several individuals from EU-funded anti-corruption NGOs 'flowed' into mainstream

\footnotetext{
${ }^{13}$ An informant from Armenia suggested that competition intensified after the country joined the Eurasian Economic Union in 2015: donors such as USAID 'exited' and CSOs became even more reliant on EU funding (informal conversation, donor organisation, 12.05.19, Yerevan).
} 
politics in the aftermath of Armenia's Velvet Revolution (Socioscope, 2019). ${ }^{14}$ When these individuals maintain strong ties to the civic sector, questions could be raised about the non-partisan character of civil society (Interview 2, 5; 6). Politicization is pushed to an extreme in Azerbaijan: antagonised by the authoritarian government, human rights activists fall within the category of “opposition actors” together with political parties (interview 15; 19; 21; Bedford and Vinatier, 2019). There also seems to be a debate about "how anti-government one has to be to truly represent [the activist community]" (Adilgizi and Kucera, 2018) and to distinguish oneself from the 'non-genuine' civil society - meaning GONGOs. Although donors try to trace boundaries and exclusively engage with "true NGOs" (Interview 16), reality is more complex: as one EU official admitted, certain actors compromise their independence and work with the authoritarian government to

"swim through the tide. But in the end we get the same complaints [on human rights issues] from GONGOs and from NGOs, so we stopped looking at this point" (Interview 15)

Blurring the lines of the hegemonic discourse, the political nature of some civic actors can play at their advantage:

"The EU mainly holds consultations with civil society and opposition political parties. Sometimes they don't know how to 'frame' us so we are invited to both consultations. For us it is only good, it is an opportunity to push our claims through" (Interview 18)

Third, and most importantly, external interventions affect not only CSOs' financial sustainability, but also their agenda and local legitimacy. Dependence from EU funding keeps local human rights CSOs trapped in-between two contrasting dynamics: on the one hand, having to act in conformity to the donor's instructions and its 'good-Other' image; on the other, a struggle for being considered legitimate actors and "reaching to the constituencies" at the grassroots level (Interview 21). These concerns are important in South Caucasus societies where the level of public trust towards the NGO sector is lower than in Western Europe and even than in other former Soviet countries (Aliyev, 2015). Human rights NGOs are often discredited by the public and the governments as "grantseaters" on the payroll of foreign powers or George Soros (Interview 5), as "15 young men and women who are travelling to Brussels every other week" (Interview 11), or even as "destabilisers of society" (in Azerbaijan; interview 17; 20; 22). One interviewee explained:

\footnotetext{
${ }^{14}$ The same happened in Georgia after the 'Rose Revolution' and in the years of the United National Movement rule, between 2004-2012 (Nodia, 2018).
} 
"Human rights organisations are not very popular in Georgia. [...] "Non-governmental organisation" is a pejorative term. We are trying to use it less and switch to "human rights organisations". But I think [people] know what a human rights organisation means, just another name for NGO”. (Interview 11)

In Armenia, where prior to the Velvet Revolution the EU had cooperated with the corrupt Republican Party (and encouraged human rights NGOs to do so - thus losing credibility in their eyes), the subalterns' quest for local legitimacy translates into a willingness to be a 'non-conformist' civil society actor (Socioscope, 2019: 22):

"We don't like to be conformist. [...] We love to preserve our neutrality from the government, from donors, and we gave a good fight to the EU [when implementing a project]. They said "we gave you the money!" and we said "sorry, this is not a service contract but a grant contract, we had very clear proposal and criteria, so you cannot now come and tell us [what we need to do]". They didn't like this. [...] But these other big NGOs did not have enough stomach to confront this issue." (Interview 3)

Moreover, respondents from across the three countries noted that donors' focus on advocacy and civic/political rights deepened the disconnect between the civic sector and the actual 'beneficiaries' of policies (Interview 7; 9; 11; 17; 20; 22; also Aliyev, 2015), which in turn generates disagreement on how to carry out human rights work:

"Sometimes we are criticised [by donors] that we are 'stubborn' because of our principles. [...] We push for community empowerment, because there are only a few [donors] that want to work on it. Working on legislation and advocacy is more favourable to get funding because the results are on paper. Community empowerment is not easy to monitor, but if you don't work on both $[\ldots]$ your advocacy will not be in line with the community needs. [...] For EU institutions it is very difficult because they need another report at the end of the year, they should see progress. That's why we want to create monitoring and evaluation tools to measure changes in the community empowerment process." (Interview 12)

Attempts to push a human rights agenda, which differs from the liberal one, and to promote more grassroots work, are sometimes met with suspicion. This requires subaltern actors to seemingly comply with the rules of the game, while subverting them:

“Our dual nature is a problem sometimes because donors don't understand whether we are a social movement or a standard NGO. This creates some problems for us. One [European] 
donor that I'm trying to seduce is careful with us: it's not convinced that we are not a political organisation. [...] We don't hide that we are a left-wing organisation and we push for social equality.

\section{Does this create problems with donors in general?}

At this stage no. We are trusted because the product [i.e. reports] is high quality. We put all our energy, our staff is going crazy to work... standards are very high. That's how we balance it I guess with donors. Being too political is balanced by giving them a good product." (Interview 11)

In navigating these tensions, some actors in Georgia and Armenia go further in criticizing (or rejecting) participation in EU-sponsored platforms for advocacy such as the EaP CSF National Platforms, which they consider "not genuinely rights-based" (Interview 9; informal conversation, Georgian NGO, 16.05.19), not representative, or not in line with their vision of human rights work:

"To what extent is [the EaP CSF] representative? You have many organisations, but some CSOs do not want to go there - they prefer protesting" (informal conversation, Armenian human rights activist, 8.11.18)

Even in Azerbaijan, where some respondents referred to the EaP CSF as "all we have left" for advocacy (Interview 16; 17; 22), others complained that the NGOs taking part in this platform consist

"of only one person who speaks on behalf of others, but is not really doing some job in the country. They spend their time reporting on projects and travelling [...] but do not really believe in what they are doing". (Interview 14)

Besides challenging the NGO model (Interview 14; 20; 21; Beraia et al., 2019), these observations raise the question whether "radical" human rights actors - those with a leftist, anti-capitalist agenda, which may have another vision of what a 'good life' is - are interested in "more engagement" with liberal norms promoters such as the EU (informal conversation, Armenian environmental movement, 2.10.19).

Finally, a way for the subaltern actors to reclaim ownership of their human rights work is to turn the "leveraged pedagogy" relation on its head, privately bashing EU representatives and experts for their lack of knowledge of "how things work in the local context" (Interview 2, 3, 5; informal 
conversation, Georgian women's rights NGO, 16.05.19). One respondent refused funding from the EU because they

“didn't want to adjust the project's content and purpose to the EU's ideology, how they want to reconstruct the post-Soviet world, what institutions it should have, without taking into account the local context". (Interview 20)

However, subaltern actors cannot always turn their back on EU funding and instructions, because they depend on this intervention for their financial survival. Here, an Armenian NGO representative was recounting a small accident with the EU Delegation, due to a misunderstanding in the implementation phase of a project:

"They started calling us bad things, they said 'you're too radical', but we dream to be radical! Sometimes you have to be a little bit conformist... if we were radicals we would never work with the EU [laughs]. But we are not radical enough unfortunately. The Delegation office here [are telling us] 'do not protest, do not protest!'. And we explain: 'we have to protest, if something is not right, we have to fight against violence, unfair decisions, we have to protest in different ways. If needed, we have to go to the streets and protest'. [...] Now many organisations are also joking with us: when there's a EU meeting they're like [whispers] 'do not protest!'. But usually we don't protest that much! We are not really aggressive or whatever. This is already a civil society joke, when there are EU meetings we tell each other [whispers, then laughs]'do not protest!’” (Interview 5)

Critical agency manifests itself creatively, in the form of inside jokes or "hidden transcripts" that subvert the hegemony through "a critique of power spoken behind the back of the dominant" (Scott, 1990: 4). Although "not revolutionary", this "provide[s] integrity in everyday life, and reconstructs legitimacy for subjects who reclaim it from power and structure” (Richmond, 2011: 428).

\section{Conclusions}

This article advanced existing critiques on the EU's engagement with civil society, as exemplified in the case of the South Caucasus, by adopting a discursive perspective. Drawing on poststructuralist and postcolonial theories, it not only critically examined how the EU constructs civil society's role in human rights promotion, but it also illustrated how this hegemonic discourse gets hybridized and subverted by actors embedded in the local contexts. 
The discursive construction of 'civil' society as a 'good-Other' of the 'EU-Self' is ripe with ambiguities and contradictions. First, this identity is articulated around signifiers of liberaldemocratic consensus, political neutrality and representativeness that do not correspond to local realities: by articulating this identity as common sense, the EU legitimises its intervention into South Caucasus countries in the name of 'approximation'. However, there is not to say 'a' civil society that the EU is claiming to empower, but rather a fragmented sphere of competing interests - which may not be necessarily 'civil'. Second, the tracing of normative and political boundaries reinforces the exclusion of societal actors from having a say on their countries' development trajectory. If one way in which the EU legitimises its attempts to transform third countries is by claiming the civil society it engages with represents the whole citizenry's needs and wishes, this 'local ownership' rhetoric contrasts starkly with the actual practices. Third, through these discursive processes human rights work is reframed from radical transformative action into a depoliticized, technical agenda aiming at the approximation of 'transitioning' countries with EU-niversal standards.

Without paying more attention to local meanings, power and legitimacy dynamics, only apparently depoliticized interventions may backfire. Across the South Caucasus, nativist civil society groups and authoritarian institutions have become increasingly vocal in contesting the so-called "liberal globalist" ideology - notably, gender and LGBT equality norms - whose "interpreter-in-chief" they identify in the "mainstream" civil society created by Western donors and allegedly disconnected from society (Nodia, 2018: 46). At a moment when human rights and civic freedoms are questioned even from within the Union, a critical reappraisal of the universalistic categories and solutions underpinning the EU's interventions seems more urgent than ever.

\section{List of Interviews}

\begin{tabular}{|l|l|l|}
\hline No. & Date & Function \\
\hline 1 & $5 / 03 / 2019$ & EU official \\
\hline 2 & $7 / 05 / 2019$ & Civil and political rights NGO, Yerevan \\
\hline 3 & $7 / 05 / 2019$ & Civil and political rights NGO, Yerevan \\
\hline 4 & $8 / 05 / 2019$ & EU official \\
\hline 5 & $8 / 05 / 2019$ & Human rights NGO, Yerevan \\
\hline 6 & $8 / 05 / 2019$ & Human rights NGO, Yerevan \\
\hline 7 & $15 / 05 / 2019$ & Human rights NGO, Tbilisi \\
\hline 8 & $16 / 05 / 2019$ & EU official \\
\hline
\end{tabular}




\begin{tabular}{|l|l|l|}
\hline 9 & $17 / 05 / 2019$ & Human rights NGO, Tbilisi \\
\hline 10 & $20 / 05 / 2019$ & Anti-corruption NGO, Tbilisi \\
\hline 11 & $20 / 05 / 2019$ & Human rights NGO, Tbilisi \\
\hline 12 & $22 / 05 / 2019$ & Community-based NGO, Tbilisi \\
\hline 13 & $22 / 05 / 2019$ & Community-based NGO, Tbilisi \\
\hline 14 & $12 / 09 / 2019$ & Gender equality activist, Baku \\
\hline 15 & $12 / 09 / 2019$ & EU official \\
\hline 16 & $13 / 09 / 2019$ & Labour rights NGO, Baku \\
\hline 17 & $13 / 09 / 2019$ & Women's rights NGO, Baku \\
\hline 18 & $13 / 09 / 2019$ & Civic activist, Baku \\
\hline 19 & $14 / 09 / 2019$ & Civil and political rights expert, Baku \\
\hline 20 & $15 / 09 / 2019$ & Human rights lawyer, Baku \\
\hline 21 & $15 / 09 / 2019$ & Human rights defender, Baku \\
\hline 22 & $16 / 09 / 2019$ & Women's rights NGO, Baku \\
\hline
\end{tabular}

\section{References}

Abramson D. (1999) A Critical Look at NGOs and Civil Society as Means to an End in Uzbekistan. Human Organization 58: 240-250.

Adilgizi L and Kucera J. (2018) Merkel visit with Azerbaijani civil society sparks controversy - among civil society. Eurasianet, 28 August. Available at: https://eurasianet.org/merkel-visit-withazerbaijani-civil-society-sparks-controversy-among-civil-society (accessed 17 January 2020).

Aliyev H. (2015) Post-Communist Civil Society and the Soviet Legacy: Challenges of Democratisation and Reform in the Caucasus: Palgrave Macmillan UK.

Aliyev H. (2016) Assessing the European Union's Assistance to Civil Society in Its Eastern Neighbourhood: Lessons from the South Caucasus. Journal of Contemporary European Studies 24: 42-60.

Andreasyan Zh, Ishkanian A, Manusyan A, et al. (2019) From shrinking space to post-revolutionary space: Reimagining the role and relations of civil society in Armenia. Analytical Report.

Socioscope, Yerevan, January. Available at: http://socioscope.am/wpcontent/uploads/2019/01/Socioscope-report 15.01 spread-eng.pdf (accessed 17 January 2020).

Axyonova V and Bossuyt F. (2016) Mapping the substance of the EU's civil society support in Central Asia: From neo-liberal to state-led civil society. Communist and Post-Communist Studies 49: 207-217.

Babajanian B, Freizer S and Stevens D. (2005) Introduction: Civil society in Central Asia and the Caucasus. Central Asian Survey 24: 209-224.

Bedford S and Vinatier L. (2019) Resisting the Irresistible: 'Failed Opposition' in Azerbaijan and Belarus Revisited. Government and Opposition 54: 686-714.

Beraia A, Yavuz H and Dilanyan S. (2019) Beyond NGOs: Decolonizing Peacebuilding and Human Rights. Journal of Conflict Transformation. Available at: https://caucasusedition.net/beyond-ngosdecolonizing-peacebuilding-and-human-rights/ (accessed 17 January 2020).

Bhabha H. (1994) The Location of Culture. London: Routledge. 
Boiten VJ. (2015) The Semantics of 'Civil': The EU, Civil Society and the Building of Democracy in Tunisia. European Foreign Affairs Review: 357-377.

Böttger K and Falkenhain M. (2011) The EU's policy towards Azerbaijan: what role for civil society? SPES Policy Papers, Institut für Europäische Politik, June.

Buzogány A. (2018) Civil Society Organisations beyond the European Union: Normative Expectations and Local Realities. Journal of Contemporary European Research 14: 187-205.

Choudry A and Kapoor D. (eds) (2013) NGOization: Complicity, Contradictions and Prospects: Zed Books.

Cooley, A and Ron J. (2002) "The NGO Scramble: Organizational Insecurity and the Political Economy of Transnational Action", International Security 27, 1: 5-39.

Council of the European Union. (2012) Council conclusions on The roots of Democracy and sustainable development: Europe's engagement with Civil Society in external relations. Available at: https://ec.europa.eu/europeaid/roots-democracy-and-sustainable-development-europesengagement-civil-society-external-relations en (accessed 17 January 2020).

Council of the European Union (2017) EU engagement with civil society in external relations. Council conclusions. Available at: https://www.consilium.europa.eu/media/24003/st10279en17conclusions-eu-engagement-with-civil-society-in-external-relations.pdf (accessed 27 August 2020).

Diez T. (2013) Normative power as hegemony. Cooperation and Conflict 48: 194-210.

Edkins J. (2007) Poststructuralism. In: Griffiths M (ed) International Relations Theory forthe TwentyFirst Century. An introduction. London: Routledge, 88-98.

European External Action Service. (2018). EU Roadmap for Engagement with Civil Society in Georgia 2018-2020. Available at: https://eeas.europa.eu/sites/eeas/files/cs roadmap 2018-2020 part $\mathrm{i}$ and ii consolidated final clean.pdf (accessed 22 April 2020).

Evans T (2005) The Politics of Human Rights: A Global Perspective. London: Pluto Press.

Feldman G. (2011) Illuminating the apparatus: Steps toward a nonlocal ethnography of global governance. In: Shore C, Wright S and Però D (eds) Policy Worlds: Anthropology and the Analysis of Contemporary Power. Oxford, New York: Berghahn Books, 32-49.

Fisher Onar N and Nicolaidis K. (2013) The Decentring Agenda: Europe as a post-colonial power. Cooperation and Conflict 48: 283-303.

Hahn-Fuhr I and Worschech S. (2014) External Democracy Promotion and Divided Civil Society-The Missing Link. In: Beichelt T, Hahn-Fuhr I, Schimmelfennig F, et al. (eds) Civil Society and Democracy Promotion. London: Palgrave Macmillan UK, 11-41.

Hansen L. (2006) Security as Practice: Discourse Analysis and the Bosnian War, London: Routledge.

Haukkala H. (2008) The European Union as a Regional Normative Hegemon: The Case of European Neighbourhood Policy. Europe-Asia Studies 60: 1601-1622.

Horký-Hlucháň O and Kratochvíl P. (2014) "Nothing Is Imposed in This Policy!":The Construction and Constriction of the European Neighbourhood. Alternatives 39: 252-270.

Hulme D and Edwards M (eds) (2013) NGOs, States and Donors: Too Close for Comfort? (2nd edn). Houndmills: Palgrave Macmillan.

Ishkanian A. (2014) Engineered Civil Society: The Impact of 20 Years of Democracy Promotion on Civil Society Development in Former Soviet Countries. In: Beichelt T, Hahn-Fuhr I, Schimmelfennig F, et al. (eds) Civil Society and Democracy Promotion. Palgrave Macmillan, 150-170.

Jørgensen MW and Phillips LJ. (2002) Discourse Analysis as Theory and Method, London, Thousand Oaks, New Dehli: SAGE Publications.

Keukeleire S and Lecocq S. (2018) Operationalising the decentring agenda: Analysing European foreign policy in a non-European and post-western world. Cooperation and Conflict 53: 277-295.

Korosteleva E. (2017) Eastern Partnership: bringing "the political" back in. East European Politics 33: 321-337.

Kulpa R. (2014) Western leveraged pedagogy of Central and Eastern Europe: discourses of homophobia, tolerance, and nationhood. Gender, Place \& Culture 21: 431-448. 
Kurki M. (2011a) Governmentality and EU Democracy Promotion: The European Instrument for Democracy and Human Rights and the Construction of Democratic Civil Societies. International Political Sociology 5: 349-366.

Kurki M. (2011b) Human Rights and Democracy Promotion: reflections on the contestation in, and the politico-economic dynamics of, rights promotion. Third World Quarterly 32: 1573-1587.

Kutay A. (2017) How Does the European Commission Create a European Civil Society with Words? A Discourse Theoretical Inquiry. JCMS: Journal of Common Market Studies 55: 1094-1109.

Laclau E and Mouffe C. (1985) Hegemony and Socialist Strategy: Towards a Radical Democratic Politics, London: Verso.

Marchetti R. (2017) Foreign Policy by Proxy: Democracy and Human Rights Promotion through an Engagement with Civil Society. In: Marchetti R (ed) Partnerships in International Policy-Making. Civil Society and Public Institutions in European and Global Affairs. London: Palgrave Macmillan, 275-292.

Matveeva A. (2008) Exporting Civil Society: The Post-Communist Experience. Problems of PostCommunism 55: 3-13.

Morozov V. (2015) Russia's Postcolonial Identity. A Subaltern Empire in a Eurocentric World, Basingstoke: Palgrave Macmillan UK.

Morozov V. (2018) Global (Post)Structural Conditions. In: Tsygankov AP (ed) Routledge Handbook of Russian Foreign Policy. London: Routledge, 22-42.

Morozova N. (2018) Resisting the West, Forging Regional Consensus: Russia's Discourse on Humanitarian Cooperation in the Commonwealth of Independent States. Geopolitics 23: 354377.

Muehlenhoff HL. (2018) Neoliberal governmentality and the (de)politicisation of LGBT rights: The case of the European Union in Turkey. Politics: 1-16.

Nodia G. (2018) Nativists Versus Global Liberalism in Georgia. In: Youngs R (ed) The Mobilization of Conservative Civil Society. Carnegie Endowment for International Peace, 45-50.

Richmond OP. (2011) Critical agency, resistance and a post-colonial civil society. Cooperation and Conflict 46: 419-440.

Rommens T. (2014) The Eastern Partnership: civil society in between the European and domestic level: the case of Georgia. East European Politics and Societies 30: 54-70.

Scott JC. (1990) Domination and the Arts of Resistance. Hidden Transcripts, Yale: Yale University Press.

Smith NR. (2011) Europeanization Through Socialization? The EU's Interaction with Civil Society Organizations in Armenia. Demokratizatsiya: The Journal of Post-Soviet Democratization 19: 385.

Vandeputte $N$ and Luciani L (2018) European Union democracy assistance: An academic state of play. European Partnership for Democracy, Brussels, January. Available at: http://epd.eu/wpcontent/uploads/2018/12/EU-Democracy-Assistance.pdf (accessed 17 January 2020).

Yanow D. (2014) Interpretive Analysis and Comparative Research. In: Engeli I and Allison CR (eds) Comparative Policy Studies: Conceptual and Methodological Challenges. London: Palgrave Macmillan UK, 131-159. 